\title{
Genetic Analyses for the White-Tailed Character of the Chabo (Japanese Bantam)
}

\author{
Masaoki Tsudzuki ${ }^{1}$, Sachio Kono ${ }^{2}$ and Yohsuke Kinoshita ${ }^{1}$ \\ ${ }^{1}$ Graduate School of Biosphere Science, Hiroshima University, Higashi-Hiroshima, Hiroshima 739-8528, Japan \\ ${ }^{2}$ Hiroshima Prefectural Livestock Technology Research Center, Shobara, Hiroshima 727-0023, Japan
}

\begin{abstract}
In the Chabo (Japanese Bantam) breed of native Japanese chickens, there are birds that have buff-like plumage. This plumage shows yellowish brown at the trunk and white for all the tail feathers and a part of the primaries. In other words, this plumage occurs when areas, normally black for "buff columbian" plumage are replaced by white ones. Genetic analyses revealed that the gene controlling the appearance of the white area is an incompletely dominant autosomal gene. The homozygous condition for the mutant gene completely inhibits the expression of black pigmentation, leading to the replacement of black areas with pure white ones. The inhibition effect in the heterozygote however, is incomplete, resulting in the white areas (feathers) that have a slight gray tinge and many minute gray or black speckles. The mutant gene also has a weak effect in inhibiting the expression of brown color. Furthermore, when birds have the mutant gene with a wild-type genetic background for other plumage color genes, they exhibited the "red-pyle" plumage pattern. Therefore, there is a high possibility that the mutant gene expressing white areas (feathers) in the Chabo is identical to the known dominant white $(I)$ gene, because the effect and mode of inheritance of the mutant gene possessed by the Chabo are quite similar to those of the $I$ gene. This could be the first finding of a dominant mutant gene controlling white plumage in Japanese fancy fowls.
\end{abstract}

Key words : Chabo, dominant white, Japanese Bantam, native Japanese chicken, plumage color mutation

\section{Introduction}

In Japan, we have $40-50$ breeds of native Japanese chickens (Tsudzuki, 2003). Almost all breeds of native Japanese chickens are ornamental breeds, of which two groups (the Jidori and Shamo groups) and 15 breeds have been designated as "Natural Monuments" by the Japanese Government (Kuroda et al., 1987). The Chabo (Japanese Bantam) breed is one of the Natural Monuments. The ancestors of the Chabo are thought to have been introduced to Japan from Vietnam around the beginning of the 17 th century (Oana, 1951), thereafter improvement has been performed for their body shape and plumage colors, and currently the Chabo breed has many plumage color varieties authorized by fancier associations (Mitsui, 1979). The buff, which has yellowishbrown plumage all over the body, is one of these varieties. However, though currently in Japan there are no birds that show complete buff plumage, there are birds that have buff-like plumage. The buff-like plumage shows white tail feathers and partially white primaries, although the trunk is yellowish brown in color (Fig. 1).

This article describes the characteristics and the mode of inheritance of the white-tailed character seen in the buff-like Chabo.

\section{Materials and Methods}

After detailed observation for the buff-like (white-

Received : October 7, 2005, Accepted : November 1, 2005

Correspondence to : Masaoki Tsudzuki, Laboratory of Animal Breeding and Genetics, Graduate School of Biosphere Science, Hiroshima University, Higashi-Hiroshima, Hiroshima 739-8528, Japan

Tel/Fax : +81-82-424-7950 E-mail : tsudzuki@hiroshima-u.ac.jp 


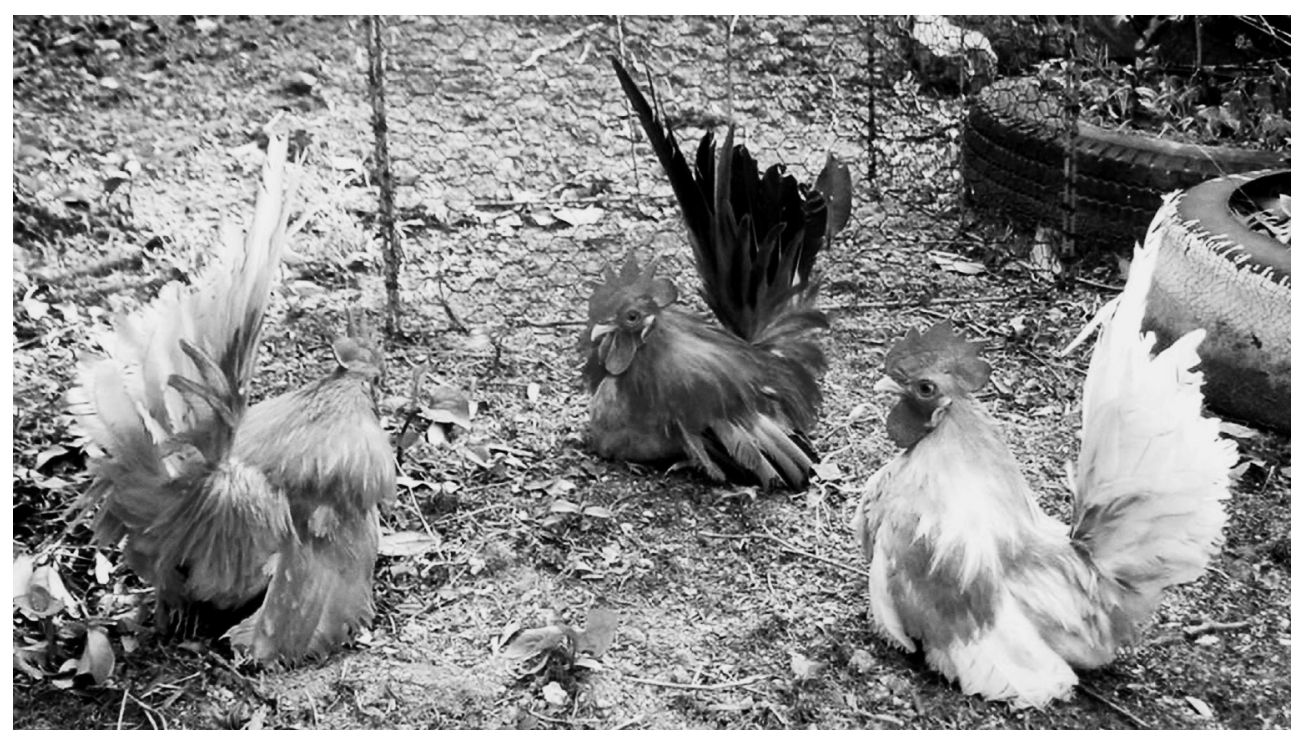

Fig. 1. Buff-like (left and right) and "buff-columbian" (middle) males of the Chabo. In buff-like (white-tailed) Chabos, black regions of the buff-columbian plumage are replaced by white. The white region in the homozygote for the mutant gene (right) is larger than the heterozygote (left). The brown coloration is also lighter in the homozygote than in the heterozygote.

Table 1. Incidence of the white-tailed character in intra-Chabo and inter-breed matings*

\begin{tabular}{|c|c|c|c|c|c|}
\hline \multirow[b]{2}{*}{ Matings } & \multicolumn{4}{|c|}{ Segregation ratios of characters } & \multirow[b]{3}{*}{$P\left(\chi^{2}\right.$-test $)$} \\
\hline & \multicolumn{3}{|c|}{ Observed } & \multirow{2}{*}{$\begin{array}{c}\text { Expected } \\
\text { WT : ST : BT }\end{array}$} & \\
\hline Female $\times$ Male & WT & ST & BT & & \\
\hline \multicolumn{6}{|l|}{ Intra-Chabo mating } \\
\hline $\mathrm{WT} \times \mathrm{WT}$ & 7 & 0 & 0 & $1: 0: 0$ & - \\
\hline $\mathrm{WT} \times \mathrm{BT}$ & 0 & 14 & 0 & $0: 1: 0$ & - \\
\hline $\mathrm{ST} \times \mathrm{ST}$ & 5 & 9 & 5 & $1: 2: 1$ & - \\
\hline $\mathrm{ST} \times \mathrm{WT}$ & 4 & 3 & 0 & $1: 1: 0$ & $\mathrm{P}=0.51^{* *}$ \\
\hline $\mathrm{BT} \times \mathrm{ST}$ & 0 & 21 & 16 & $0: 1: 1$ & $.50>P>.40$ \\
\hline \multicolumn{6}{|l|}{ Inter-breed mating } \\
\hline Brown Leghorn $(\mathrm{BT}) \times \mathrm{WT}$ Chabo & 0 & 40 & 0 & $0: 1: 0$ & - \\
\hline $\mathrm{F}_{1}(\mathrm{ST}) \times \mathrm{F}_{1}(\mathrm{ST})$ & 13 & 14 & 6 & $1: 2: 1$ & $.20>P>.10$ \\
\hline $\mathrm{F}_{1}(\mathrm{ST}) \times$ Brown Leghorn $(\mathrm{BT})$ & 0 & 16 & 18 & $0: 1: 1$ & $.80>P>.70$ \\
\hline
\end{tabular}

$* \mathrm{WT}=$ white tail, $\mathrm{ST}=$ speckled tail, $\mathrm{BT}=$ black tail .

** Binomial test.

tailed) character, we performed two kinds of mating experiments. One is an intra-Chabo mating, taking the combination of tail colors into consideration. In the mating experiment, we set up five kinds of combination of tail colors (Table 1). All the Chabos used here had the Co/Co $e^{y} / e^{y}$ genotype for plumage color genes in the background.

A second mating experiment is an inter-breed mating with white-tailed Chabos and Brown Leghorns that have wild-type plumage with black tail feathers. In this experiment, we performed inter se matings of the $F_{1}$ birds derived from the matings of the Chabo and the Brown Leghorn breeds to produce $F_{2}$ progeny. Subsequently, we mated the $F_{1}$ birds to the Brown Leghorns to obtain a backcross generation (Table 1).

We examined segregation ratios for tail color characters for each mating in both the intra- and inter-breed mating experiments. Finally, the data from the intra- and inter-breed matings were com- 
Table 2. Summary of incidence of the white-tailed character in mating experiments*

\begin{tabular}{|c|c|c|c|c|c|}
\hline \multirow{3}{*}{$\begin{array}{c}\text { Matings } \\
\text { Female } \times \text { Male }\end{array}$} & \multicolumn{4}{|c|}{ Segregation ratios of characters } & \multirow[b]{3}{*}{$P\left(\chi^{2}\right.$-test $)$} \\
\hline & \multicolumn{3}{|c|}{ Observed } & \multirow{2}{*}{$\begin{array}{c}\text { Expected } \\
\text { WT : ST : BT }\end{array}$} & \\
\hline & WT & ST & BT & & \\
\hline $\mathrm{WT} \times \mathrm{WT}$ & 7 & 0 & 0 & $1: 0: 0$ & - \\
\hline $\mathrm{WT} \times \mathrm{BT}$ & 0 & 14 & 0 & $0: 1: 0$ & - \\
\hline $\mathrm{BT} \times \mathrm{WT}$ & 0 & 40 & 0 & $0: 1: 0$ & - \\
\hline Total & 0 & 54 & 0 & $0: 1: 0$ & - \\
\hline $\mathrm{ST} \times \mathrm{ST}$ & 18 & 23 & 11 & $1: 2: 1$ & $.30>P>.20$ \\
\hline $\mathrm{ST} \times \mathrm{WT}$ & 4 & 3 & 0 & $1: 1: 0$ & $\mathrm{P}=0.51^{* *}$ \\
\hline $\mathrm{BT} \times \mathrm{ST}$ & 0 & 21 & 16 & $0: 1: 1$ & $.50>P>.40$ \\
\hline $\mathrm{ST} \times \mathrm{BT}$ & 0 & 16 & 18 & $0: 1: 1$ & $.80>P>.70$ \\
\hline Total & 0 & 37 & 34 & $0: 1: 1$ & $.80>P>.70$ \\
\hline
\end{tabular}

$* \mathrm{WT}=$ white tail, $\mathrm{ST}=$ speckled tail, $\mathrm{BT}=$ black tail.

** Binomial test.

bined, to take the combination of tail colors in matings into consideration (Table 2). Statistical analyses for the segregation ratios were performed by the $\chi^{2}$-test or binomial-test.

\section{Results and Discussion}

\section{Morphology}

The primary plumage pattern of the buff-like Chabo is the same as that of the "buff columbian" plumage (Smyth and Somes, 1965 ; Brumbaugh and Hollander, 1966 ; Smyth, 1990). In the buff-like Chabo plumage, the black areas of the buffcolumbian plumage (i.e. tail feathers and a part of the primaries) were replaced by white ones (Fig. 1). Detailed observation revealed that there are two types of plumage for the buff-like Chabos. One is a bird that shows pure white in the white region, and the other has a light grayish tinge and minute gray or black speckles in the white region (feathers) (Fig. $2)$. Hereafter, for the convenience of description, we will call the former type character "White Tail" (WT) and the latter type character "Speckled Tail" (ST). Also, we will call the character showing no white areas "Black Tail" (BT). In the ST Chabo, the brown color in plumage was lighter than that of the BT Chabo. In the WT Chabo, the brown color was lighter than that of the ST Chabo. Moreover, in the WT Chabo, some of the hackles, saddle hackles, tail coverts, primaries, and secondaries, which are originally brown in color, were whitish or white (Fig. 1).

\section{Mode of inheritance}

Table 1 shows the results of intra-Chabo matings

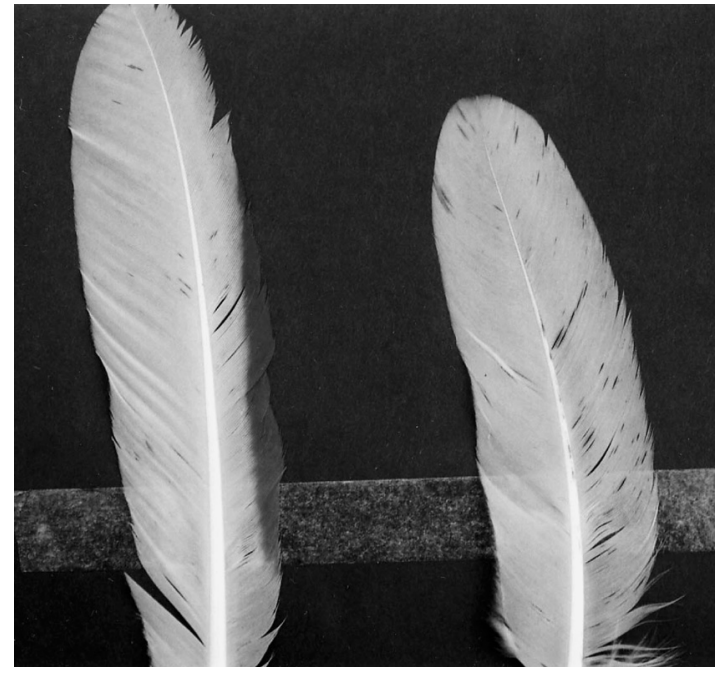

Fig. 2. Feathers from a buff-like (white-tailed) cock heterozygous for the mutant gene. Left : a primary feather. Right : a tail feather. In both feathers, minute gray or black speckles are seen.

and inter-breed matings. The data from the intraChabo mating suggested that the white-tailed character of the Chabo is controlled by an incompletely dominant autosomal gene. In the inter-breed mating, all the $F_{1}$ progeny showed ST. In the $F_{2}$ generation obtained by the inter se matings of ST birds, WT, $\mathrm{ST}$, and BT segregated in a ratio of $1: 2: 1$. In the backcross generation obtained by matings of the $F_{1}$ (ST) and the Brown Leghorn (BT), ST and BT segregated in a ratio of $1: 1$. The data from interbreed matings also suggested incompletely dominant autosomal inheritance. Then, the data from the intra- and inter-breed matings were combined based 


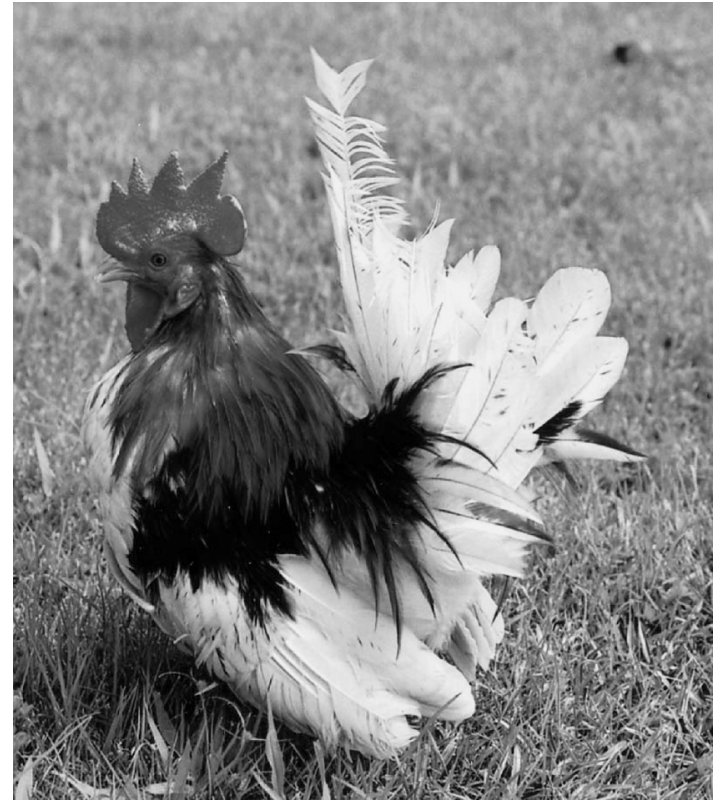

Fig. 3. The red-pyle plumage. The black areas in the wild-type plumage are replaced by white. This male is heterozygous for the mutant gene, in which gray or black minute speckles appear in the white region.

on the combinations of tail colors in matings, because there was essentially no difference in the segregation ratios of tail characters between the two kinds of matings. The combined data are shown in Table 2. WT parents produced only WT progeny. The reciprocal matings of WT and BT birds produced ST progeny only. The inter se matings of ST birds produced WT, ST, and BT progeny in a $1: 2$ : 1 ratio. The matings of ST and WT birds produced ST and WT progeny in a $1: 1$ ratio. In the reciprocal matings between the BT and ST birds, ST and BT birds segregated in a ratio of $1: 1$. All ratios obtained from each mating were in agreement with the expected ratios, based on the hypothesis that the white-tailed character seen in the Chabo is controlled by an autosomal dominant mutant gene and the gene effect is incomplete under the heterozygous condition.

In the $F_{2}$ and backcross generations of the interbreed mating, the males having the combination of the mentioned mutant gene and the wild-type $\left(\mathrm{Co}^{+} /\right.$ $\left.\mathrm{co}^{+} e^{+} / e^{+}\right)$background showed the "red-pyle" plumage pattern (Fig. 3) - that is, the black regions of the black-breasted red (wild-type) plumage were replaced by white ones (Somes, 1988 ; Smyth, 1990 ; Roberts, 1997).
Thus, it can be concluded that the mutant gene is an inhibitor to black pigmentation, the homozygote exhibits pure white feathers instead of black feathers, and the heterozygote expresses white feathers with a light gray tinge and minute gray or black speckles. Furthermore, judging from the observation of the two types of white-tailed Chabos (Fig. 1 ), it is apparent that the mutant gene has a dilution effect on brown pigmentation. The effect is thought to be more intensive in homozygotes than in heterozygotes. These characteristics and mode of inheritance of the mutant gene in question are quite similar to those of the known dominant white $(I)$ gene. The $I$ gene also is an incompletely dominant autosomal gene that inhibits black pigmentation and dilutes brown pigmentation, and exhibits the "red-pyle" plumage pattern under a wild-type genetic background (Somes, 1988 ; Smyth, 1990). Thus, there is a high possibility that the mutant gene is identical to the $I$ gene. Recently, the dominant white mutation (I) was revealed to be exclusively associated with a 9-bp insertion in exon 10 of the PMEL17 gene (Kerje et al., 2004). Molecular analyses for the PMEL17 gene possessed by the white-tailed Chabo will resolve this problem in the future. Regardless of the aforementioned, this could be the first finding of a dominant gene controlling white plumage in Japanese fancy fowls.

\section{References}

Brumbaugh JA and Hollander WF. Genetics of buff and related color patterns in the fowl. Poultry Science, 45, 451-457. 1966.

Kerje S, Sharma P, Gunnarsson U, Kim H, Bagchi S, Fredriksson $R$, Schütz $K$, Jensen $P$, von Heijne $G$, Okimoto $\mathrm{R}$ and Andersson L. The dominant white, dun and smoky color variants in chicken are associated with insertion/deletion polymorphisms in the PMEL17 gene. Genetics, 168, 1507-1518. 2004.

Kuroda N, Yamaguchi T, Tanabe Y and Ichinoe K. Japanese Chickens as Natural Monuments (in Japanese). Kyoikusha. Tokyo. 1987.

Mitsui T. General View of Native Japanese Chickens (in Japanese). Petlife-Sha. Tokyo. 1979.

Oana H. The Histories of Native Japanese Chickens (in Japanese). Nihonkei-Kenkyusha. Tokyo. 1951.

Roberts V. British Poultry Standards. Blackwell Science. Oxford. 1997.

Smyth JR, Jr and Somes RG, Jr. A new gene determining the columbian feather pattern in the fowl. The Journal of Heredity, 56, 151-156. 1965.

Smyth JR, Jr. Genetics of plumage, skin and eye pigmentation in chickens. In : Poultry Breeding and Genetics 
(Crawford RD ed.). pp. 109-167. Elsevier. Amsterdam. 1990.

Somes RJ, Jr. International Registry of Poultry Genetic Stocks. Storrs Agricultural Experiment Station, The University of Connecticut. Storrs. 1988.
Tsudzuki M. Japanese native chickens. In : The Relationship between Indigenous Animals and Humans in APEC Region (Chang HL and Huang YC eds.). pp. 91-116. The Chinese Society of Animal Science, Taiwan. Tainan. 2003. 